\title{
A Review of Orthodontic Indices
}

\author{
Dr Alka Gupta,' Dr Rabindra Man Shrestha² \\ 'PG Resident, "Associate Professor \\ Dept of Orthodontics, Kantipur Dental College, Kathmandu, Nepal \\ Correspondence: Dr Rabindra Man Shrestha; email: rabindraortho@gmail.com
}

\section{ABSTRACT}

Orthodontic indices are essential component in assessing severity, complexity and treatment outcome of malocclusion. Moreover, they are useful in evaluating treatment need, funding for treatment cost and public health aspects of orthodontic treatment. The present article reviews orthodontic indices used for clinical and epidemiologic purposes. The article attempts to classify the indices in qualitative and quantitative methods based on the description given by the respective authors. The indices are presented in chronological order in tabular form.

\section{INTRODUCTION}

British Society of Orthodontics in 1922 defined orthodontic specialty as, 'Orthodontics includes the study of the growth and development of the jaws and face particularly, and the body generally as influencing the position of the teeth; the study of action and reaction of internal and external influences on the development and the prevention and correction of arrested and perverted development'. '

The evaluation of malocclusion is the essential component in establishing the diagnosis and treatment need of the orthodontic patient. One of the major problems in studying malocclusion is the availability of a suitable objective method for recording the occurrence and severity of orthodontic problem. Thus, orthodontic indices are used in clinical and epidemiological studies of malocclusion. The index comprise of numerical values describing the relative status of a population on a graduated scale with definite upper and lower limits, which is designed to permit comparison with other populations classified by the same criteria and methods. ${ }^{2}$ However, none of the indices can be considered ideal for all purpose, accurate, valid and reliable for assessing the malocclusion for the priority of treatment need, allocating limited resources and assessing treatment outcomes. ${ }^{3}$

The objective of this article is to review the historical aspects of various orthodontic indices, provide their brief description and to classify them.

\section{Requirements of an ideal index (WHO ${ }^{4}$}

1. Classification is expressed by a finite scale with definite upper and lower limits; running by progressive gradation from zero (absence of disease), to the ultimate point (disease in its terminal stage).

2. The index should be equally sensitive throughout the scale.

3. The score should correspond closely with the clinical importance of the disease stage it represents.

4. Index value should be amendable to statistical analysis.

5. The index must be reproducible.

6. The index should also be simple, accurate and yield itself to modification for the collection of data.

7. The examination procedure should require a minimum of judgment.

8. The index should be simple enough to permit the study of a large population without undue cost in time or energy.

9. The examination required should be performed quickly, to evidence to a group variation.

10. The index should be valid during time.

Angle in 1899 classified malocclusion, after which numerous classification methods evolved. However, qualitative methods of classifications were found to be not suitable for measuring the severity and treatment needs. The WHO/FDI basic method recorded symptoms of malocclusion with carefully defined criteria. This method was essentially derived from the principle developed for recording individual traits of malocclusion by Bjork et al.

Initially, occlusal indices were used as an epidemiological tool to rank or classify the occlusion. During 1950s and 1960s, many occlusal indices were introduced. William Shaw and co-workers in 1995 classified occlusal indices into five following groups. 


\section{Diagnostic indices}

- Angle Classification System (1899)

- Incisal categories of Ballard \& Wayman (1964) ${ }^{9}$

- Five-point system of Ackerman \& Proffit (1969) ${ }^{10}$

\section{Epidemiologic indices}

- Index of Tooth Position (Massler \& Frankel, 1951)"11

- Malalignment Index (Van Kirk \& Pennel, 1959) ${ }^{12}$

- Occlusal Feature Index (Poulton \& Aaronson, $1961)^{13}$

- The Bjork Method $(1964)^{6}$

- Summers' Occlusal Index (1971) $1^{14}$

- The FDI method (Baume et al, 1973) ${ }^{15}$

- Little's Irregularity Index (1975) ${ }^{16}$

\section{Orthodontic treatment need indices}

- Handicapping Labio-lingual Deviation index (HLD) (Draker, 1960, 1967) $)^{17}$

- Swedish Medical Board Index (SMHB 1966; Linder Aronson, 1974, 1976) ${ }^{18,19}$

- Dental Aesthetic Index (DAl) (Cons et al, 1986)20

- Index of Orthodontic treatment Need (IOTN) (Brook \& Shaw, 1989) ${ }^{21}$

- Index of Complexity, Outcome \& Need (ICON) (Daniel \& Richmond, 2000) ${ }^{22}$

\section{Orthodontic Treatment Outcome indices}

- Peer Assessment Rating Index (PAR) (Richmond et al, 1992 $)^{23}$

- Index of Complexity, Outcome \& Need (ICON) $(2000)^{22}$

\section{Orthodontic Treatment Complexity Indices}

- Index of Orthodontic Treatment Complexity (IOTC) (Liewellyn et al, 2007) ${ }^{24}$

- Index of Complexity, Outcome \& Need (ICON) $(2000)^{22}$

The method for recording malocclusion can be classified into qualitative and quantitative methods. ${ }^{25}$ Qualitative method describes the occlusal features and provides descriptive classification of the dentition, however does not provide any information of the treatment need and outcome. Malocclusion symptoms are recorded in all or none manner as the studies on epidemiology of malocclusion do not define the method of measuring the variables. ${ }^{26}$

Quantitative methods quantify the complexity and severity of the problem rated in a scale or proportion. They are used to prioritize the need for treatment. Their use minimizes the subjectivity related to the diagnosis, outcome and complexity assessment of orthodontic treatment.

Qualitative methods of measuring malocclusion

\begin{tabular}{|c|c|}
\hline Index & Description \\
\hline Angle $(1899)^{8}$ & $\begin{array}{l}\text { - Malocclusion is classified into } 3 \text { distinct types based on molar relationship. } \\
\text { - } \quad \text { Devised as a prescription for treatment planning. } \\
\text { recognized classification mostly used in epidemiological studies. } \\
\text { - } \quad \text { The index has been criticized by Graber (1972), Rinchuse (1988). } .^{28}\end{array}$ \\
\hline Stallard $(1932)^{29}$ & - General dental status, including some malocclusion symptoms are recorded \\
\hline McCall $(1944)^{30}$ & $\begin{array}{l}\text { - Include molar relationship, posterior crossbite, anterior crowding, rotated incisors, } \\
\text { excessive overbite, open bite, labo/linguo version, tooth displacement, constriction of } \\
\text { arches. }\end{array}$ \\
\hline Sclare $(1945)^{31}$ & $\begin{array}{l}\text { - Include Angle classification of molar relationship, arch constriction with/without incisor } \\
\text { crowding, superior protrusion with/without incisor crowding, labial prominence of canines, } \\
\text { lingually placed incisors, rotated incisors, crossbite, open bite and closed bite. }\end{array}$ \\
\hline $\begin{array}{l}\text { Index of Tooth Position } \\
\text { - Massler \& Frankel (1951) } 11\end{array}$ & $\begin{array}{l}\text { - Displacement and rotation of the tooth are measured. } \\
\text { The recorded data is used to evaluate the incidence and prevalence of malocclusion in } \\
\text { population group. }\end{array}$ \\
\hline $\begin{array}{l}\text { Malalignment Index } \\
\text { - Van Kirk \& Pennel (1959) }\end{array}$ & $\begin{array}{l}\text { - Involve grading of the tooth displacement and rotation } \\
\text { - Quantitatively defines tooth displacement }(<1.5 \mathrm{~mm} \text { or }>1.5 \mathrm{~mm}) \text { and tooth rotation }\left(<45^{\circ}\right. \\
\text { or }>45^{\circ} \text { ) }\end{array}$ \\
\hline Fisk $(1960)^{32}$ & $\begin{array}{l}\text { - Dental age is used for grouping the patients. } \\
\text { Three planes of space are considered: } \\
\text { 1. Antero-postero relationship: Angle classification, anterior crossbite, overjet, negative } \\
\text { overjet } \\
\text { 2. Transverse relationship: Posterior crossbite } \\
\text { 3. Vertical relationship: Openbite, overbite } \\
\text { Additional considerations include labio-lingual spread (Draker, 1960), }{ }^{17} \text { spacing, } \\
\text { therapeutic extractions, postnatal defects, congenital defects, mutilation, congenital } \\
\text { absence, supernumerary teeth. }\end{array}$ \\
\hline
\end{tabular}




\begin{tabular}{|c|c|}
\hline Bjork, Krebs \& Solow $(1964)^{6}$ & $\begin{array}{l}\text { - Objective registration of malocclusion symptoms based on detailed definitions. } \\
\text { - } \quad \text { Data obtained could be analyzed by computers. } \\
\text { - } \quad \text { Following three parts are considered: } \\
\text { 1. Anomalies of dentition: Tooth anomalies, abnormal eruption, malalignment of } \\
\text { individual teeth. } \\
\text { 2. Occlusal anomalies: Deviation in the positional relationship between upper and } \\
\text { 3. Deviations in space conditions: Spacing or crowding. }\end{array}$ \\
\hline $\begin{array}{l}\text { Incisal categories } \\
\text { Ballard \& Wayman }(1965)^{9}\end{array}$ & $\begin{array}{l}\text { - } \quad \text { Also known as British Standards Institute Classification } \\
\text { - Considered more reliable to Angle classification as posterior teeth relation did not } \\
\text { influence the incisor occlusion } \\
\text { - } \quad \text { Based on the relationship of incisal edges of upper and lower incisors. }\end{array}$ \\
\hline $\begin{array}{l}\text { Five-point system } \\
\text { - Ackerman \& Proffit }(1969)^{10}\end{array}$ & $\begin{array}{l}\text { - } \quad \text { Five major characteristics of malocclusion are represented through a Venn diagram. } \\
\text { - Incorporates evaluation of crowding and asymmetry within the dental arches } \\
\text { - Includes transverse, vertical and antero-posterior planes of space } \\
\text { - Incorporates information about skeletal jaw proportions } \\
\text { Five-step procedure of assessing malocclusion: } \\
\text { 1. Alignment: Ideal, crowding, spacing, mutilated. } \\
\text { 2. Profile: Mandibular prominence, mandibular recession, lip profile relative to nose } \\
\text { 3. Crossbite: Relationship of dental arches in the transverse plane, as indicated by } \\
\text { 4. Angle classification: Relationship of the dental arches in the sagittal plane } \\
\text { 5. Bite depth: Relationship of the dental arches in vertical plane, as indicated by the } \\
\text { presence/absence of anterior/posterior open bite and posterior collapsed bite. }\end{array}$ \\
\hline $\begin{array}{l}\text { WHO/FDI method } \\
\text { - Baume et al (1979) }\end{array}$ & $\begin{array}{l}\text { - Method of measuring occlusal traits developed by Federation Dentaire' Internationale } \\
\text { (FDI) Commission on Classification \& Statistics for Oral Conditions (COCSTOC). } \\
\text { Aimed at developing a system of measuring occlusion which could be used widely with } \\
\text { the result being comparable. } \\
\text { Five major groups are recorded as follows: } \\
\text { 1. Gross anomalies } \\
\text { 2. Dentition: Absent teeth, supernumerary teeth, malformed incisors, ectopic eruption } \\
\text { 3. Spaced condition: Diastema, crowding, spacing } \\
\text { 4. Occlusion: } \\
\text { a. Incisor segment: Maxillary/mandibular overjet, overbite, openbite, crossbite } \\
\text { b. Lateral segment: antero-posterior relations, open bite, posterior crossbite } \\
\text { 5. Orthodontic treatment need judged subjectively: Not necessary, doubtful, } \\
\text { necessary. }\end{array}$ \\
\hline $\begin{array}{l}\text { Memorandum of } \\
\text { Orthodontic Screening \& } \\
\text { Indications for Orthodontic } \\
\text { Treatment (1990) }\end{array}$ & - $\quad$ Proposed by Danish National Board of Health to assess orthodontic treatment need \\
\hline $\begin{array}{l}\text { Grade Index Scale for } \\
\text { Assessment of Treatment } \\
\text { Need (GISATN) } \\
\text {-Salonen, Mohlin et al(1992) })^{34}\end{array}$ & - Developed in Sweden as a malocclusion index for treatment need \\
\hline $\begin{array}{l}\text { 5-Year-Olds' Index } \\
\text { - Atack et al (1997) }\end{array}$ & $\begin{array}{l}\text { - Frequently used index for cleft lip and palate cases in deciduous dentition } \\
\text { - Applied reliably to photographs of models }{ }^{36} \text { and to clinical photographs. } \\
\text { - Predicted long term outcome is divided into five following groups: } \\
\text { 1. Excellent: Positive overjet with average inclined/retroclined incisors, no crossbite/ } \\
\text { openbite, good maxillary shape and palatal anatomy } \\
\text { 2. Good: Positive overjet with average inclined/ proclined incisors, unilateral crossbite } \\
\text { or crossbite tendency, open bite tendency around cleft site } \\
\text { 3. Fair: Edge-to-edge bite with average inclined or proclined incisors; or reverse overjet } \\
\text { 4. Poor: Reverse overjet with average inclined or proclined incisors, unilateral crossbite, } \\
\text { bilateral crossbite, open bite around cleft site } \\
\text { 5. Very poor: Reverse overjet with proclined incisors, bilateral crossbite, poor maxillary } \\
\text { arch form and palatal vault anatomy }\end{array}$ \\
\hline
\end{tabular}


Quantitative methods of measuring malocclusion

\begin{tabular}{|c|c|}
\hline Index & Description \\
\hline $\begin{array}{l}\text { Handicapping Labiolingual } \\
\text { Deviation Index (HLDI) } \\
\text { - Draker (1960) }{ }^{17}\end{array}$ & $\begin{array}{l}\text { - Measurement include cleft palate, traumatic deviations (all or none), overjet, overbite, } \\
\text { - Thandibular protrusion, anterior openbite and labio-lingual spread } \\
\text { formula for overjet and overbite. } \\
\text { - The modified HLD (CalMod) index included deep impinging bites and crossbites of } \\
\text { individual anterior tooth with tissue destruction (Parker 1998) }\end{array}$ \\
\hline $\begin{array}{l}\text { Malocclusion Severity } \\
\text { Estimate } \\
\text { - Grainger (1960-61) }\end{array}$ & $\begin{array}{l}\text { - Seven weighted and defined measurements are: Overjet, overbite, anterior open } \\
\text { bite, congenitally missing maxillary incisors, molar relationship, posterior crossbite, tooth } \\
\text { displacement (actual and potential). } \\
\text { - Six malocclusion syndromes are defined as follows: } \\
\text { 1. Positive overjet and anterior openbite } \\
\text { 2. Positive overjet, positive overbite, distal molar relationship and posterior crossbite with } \\
\text { 3. Negillary teeth buccal to mandibular teeth } \\
\text { 4. Coeth lingual to mandibular teeth } \\
\text { 5. Tooth displacement } \\
\text { 6. Potential tooth displacement }\end{array}$ \\
\hline $\begin{array}{l}\text { Occlusal Feature Index (OFI) } \\
\text { - Poulton \& Aaronson (1961) }\end{array}$ & $\begin{array}{l}\text { - Measures four occlusal features: lower anterior crowding, cuspal interdigitation, vertical } \\
\text { overbite and horizontal overjet. } \\
\text { Scoring done according following criteria: } \\
\text { Slight: No need for orthodontic treatment } \\
\text { Mild: Some variation from ideal occlusion but not sufficient to need treatment } \\
\text { Moderate: Orthodontic treatment indicated and would be beneficial } \\
\text { Severe: Treatment essential }\end{array}$ \\
\hline $\begin{array}{l}\text { Occlusal Index (OI) } \\
\text { - Summers, Arbor (1966, } \\
1971)^{14}\end{array}$ & $\begin{array}{l}\text { - Valid tool for measuring occlusion and malocclusion for epidemiological purpose. } \\
\text { - } \quad \text { Different scoring scheme for deciduous, mixed and permanent dentition. } \\
\text { crossbite, posterior openbite, tooth, displacement, midline relation, maxillary median } \\
\text { diastema, congenitally missing maxillary incisors } \\
\text { - Seven malocclusion syndromes are: } \\
\text { 1. Overjet and openbite } \\
\text { 2. Distal molar relation, overbite, overbite, posterior crossbite, midline diastema and } \\
\text { 3. Congenitally missing maxillary incisors } \\
\text { 4. Tooth displacement } \\
\text { 5. Posterior open bite } \\
\text { 6. Mesial molar relation, overjet, overbite, posterior crossbite, midline diastema and } \\
\text { 7. Midline deviation }\end{array}$ \\
\hline $\begin{array}{l}\text { Swedish Medical Board } \\
\text { Index (SMBI) } \\
\text { - SMHB }(1966) \text {; -Linder- } \\
\text { Aronson }(1974,1976)^{18,19}\end{array}$ & $\begin{array}{l}\text { - } \quad \text { Developed by Swedish Medical Health Board } \\
\text { - } \quad \text { Treatment need is represented by } 4 \text { categories (Grade } 1 \text { to 4); } \\
\text { - } \quad \text { Categorized as Grade 4-0; very urgent need, urgent need, moderate need, little need } \\
\text { and no need. } \\
\text { - Features like esthetically and/or functionally handicapping anomalies such as cleft lip } \\
\text { and palate, aplasia, occlusion, deep bite, open bite, crossbite, scissors bite, overjet, } \\
\text { crowding, spacing, rotation, retained teeth are considered. }\end{array}$ \\
\hline $\begin{array}{l}\text { Treatment Priority Index (TPI) } \\
\text { - Grainger }(1967)^{41}\end{array}$ & $\begin{array}{l}\text { - Eleven weighted and defined measurements are: upper anterior segment overjet, } \\
\text { lower anterior segment overjet, overbite of upper anterior over lower anterior, anterior } \\
\text { openbite, congenital absence of incisors, distal molar relation, mesial molar relation, } \\
\text { posterior crossbite (buccal), posterior crossbite (lingual), tooth displacement, gross } \\
\text { anomalies } \\
\text { - Seven malocclusion syndromes are: Maxillary expansion syndrome, overbite, } \\
\text { retrognathism, openbite, prognathism, maxillary collapse syndrome, congenitally missing } \\
\text { incisors }\end{array}$ \\
\hline
\end{tabular}




\begin{tabular}{|c|c|}
\hline $\begin{array}{l}\text { Handicapping Malocclusion } \\
\text { Assessment Index (HMAR) } \\
\text { - Salzmann }(1968)^{42}\end{array}$ & $\begin{array}{l}\text { - Weighted measurements consist of following three parts: } \\
\text { 1. Intra-arch deviation: Missing, crowding, rotations, spacing } \\
\text { 2. Inter-arch deviation: Overjet, overbite, crossbite, open bite mesiodistal deviation } \\
\text { 3. Six handicapping dentofacial deformities: Facial and oral clefts, lower lip palatal to } \\
\text { maxillary incisors, occlusal interferences, functional jaw limitation, facial asymmetry, } \\
\text { speech impairment }\end{array}$ \\
\hline $\begin{array}{l}\text { Eismann Index (El) } \\
\text { - Eismann }(1974)^{43}\end{array}$ & $\begin{array}{l}\text { - } \quad \text { Based on Bjork's method } \\
\text { - Objective method of measuring malocclusion and assessing the efficacy of orthodontic } \\
\text { treatment } \\
\text { - } \quad \text { Based on numerical evaluation of } 15 \text { morphological traits of malocclusion } \\
\text { - Modified by Farcnik et al in Slovenia. }{ }^{44.45}\end{array}$ \\
\hline $\begin{array}{l}\text { Irregularity Index } \\
\text { - Little }(1975)^{16}\end{array}$ & $\begin{array}{l}\text { - Simple, reliable and valid method of measuring linear displacement of the anatomic } \\
\text { contact point } \\
\text { Used by public health and insurance program to establish the severity of malocclusion } \\
\text { and priority of treatment. } \\
\text { - Five linear displacement of adjacent contact point starting from mesial of right lower } \\
\text { canine to mesial of left lower canine are recorded. } \\
\text { - Model cast is ranked on a scale ranging from 0-10. }\end{array}$ \\
\hline $\begin{array}{l}\text { Dental Aesthetic Index (DAI) } \\
\text { - Cons et al }(1986)^{20}\end{array}$ & $\begin{array}{l}\text { - Developed in USA } \\
\text { - Integrated into International Collaboration Study of Oral Health Outcomes by WHO as an } \\
\text { international index } \\
\text { - Links clinical and aesthetic components mathematically to produce a single score that } \\
\text { combines physical and aesthetic aspects of occlusion, including patient perceptions. }\end{array}$ \\
\hline $\begin{array}{l}\text { Goslon Yardstick Index } \\
\text { - Mars et al (1987) }\end{array}$ & $\begin{array}{l}\text { - Used in Great Ormond Street, London and Oslo. } \\
\text { Clinical tool that allows the categorization of dental relationships in late mixed dentition } \\
\text { and early permanent dentition into five discrete categories } \\
\text { Group 1: Excellent- No treatment } \\
\text { Group 2: Good- Simple orthodontic treatment/ no treatment } \\
\text { Group 3: Fair- Complex orthodontic treatment, good result anticipated } \\
\text { Group4: Poor- Limited orthodontic treatment without orthognathic surgery if growth is } \\
\text { favorable } \\
\text { Group 5: Very poor- Orthognathic surgery, categorizes malocclusion in cleft lip \& } \\
\text { palate. }\end{array}$ \\
\hline $\begin{array}{l}\text { Standardized Continuum } \\
\text { of Aesthetic Need (SCAN } \\
\text { Index) } \\
\text { - Evans \& Shaw }(1987)^{47}\end{array}$ & $\begin{array}{l}\text { - Developed in UK } \\
\text { - Dental occlusion is matched with overall dental attractiveness against ten-scaled } \\
\text { photographs of Aesthetic Component of IOTN. } \\
\text { - Useful in state-funded hospital services. }\end{array}$ \\
\hline $\begin{array}{l}\text { Index of Orthodontic } \\
\text { Treatment Need (IOTN) } \\
\text { - Brook \& Shaw (1989) }\end{array}$ & $\begin{array}{l}\text { - IOTN has two components: Dental health component (DHC) and Aesthetic component } \\
\text { (AC). } \\
\text { DHC comprise of five grades of treatment need ranging from Grade 1-5; none, little, } \\
\text { moderate, great \& very great. } \\
\text { - Features like displacement, overjet, crossbite, openbite, occlusion, hypodontia, defects } \\
\text { of cleft lip and palate, overjet, impeded eruption, supernumerary teeth, retained } \\
\text { deciduous teeth, other pathologic cause } \\
\text { - Aesthetic Component consists of 10-grade standard reference photographs representing } \\
\text { different grades of dental attractiveness. }\end{array}$ \\
\hline $\begin{array}{l}\text { Peer Assessment Rating } \\
\text { (PAR) Index } \\
\text { - Richmond }(1992)^{23}\end{array}$ & $\begin{array}{l}\text { - Comprise of } 11 \text { following components; upper right segment, upper anterior segment, } \\
\text { upper left segment, lower right segment, lower anterior segment, lower left segment, right } \\
\text { buccal occlusion, overjet, overbite, centre line \& left buccal occlusion. }\end{array}$ \\
\hline $\begin{array}{l}\text { Norwegian Orthodontic } \\
\text { Treatment Index (NOTI) } \\
\text { - Espeland, Ivarsso, Stenvik } \\
(1992)^{48}\end{array}$ & $\begin{array}{l}\text { - A new approach to the combination of public and private funding of treatment to } \\
\text { determine the level of public health copayment to the patient. } \\
\text { On morphologic and functional basis, four groups defined are: very great, great, obvious, } \\
\text { little/no need } \\
\text { - Used in total reimbursement for severe malocclusion with cleft lip and palate, and partial } \\
\text { or nil reimbursement for other malocclusions. }\end{array}$ \\
\hline
\end{tabular}




\begin{tabular}{|c|c|}
\hline $\begin{array}{l}\text { Risk of Malocclusion } \\
\text { Assessment Index (ROMA } \\
\text { Index) } \\
\text { - Russo, Grippaudo }(1998)^{49}\end{array}$ & $\begin{array}{l}\text { - Tool to assess treatment need and validated instrument to evaluate the malocclusion risk } \\
\text { in children with mixed dentition } \\
\text { - Used to individuate not only orthodontic treatment need for children in growing age but } \\
\text { also intervention time and treatment costs in the strength of severity of score. } \\
\text { Identifies } 5 \text { grades considering negative effects of malocclusion on both dento-skeletal } \\
\text { apparatus and on psycho-social wellbeing. }\end{array}$ \\
\hline $\begin{array}{l}\text { Index of Complexity, } \\
\text { Outcome \& Need (ICON) } \\
\text { - Daniels \& Richmond (2000) }{ }^{22}\end{array}$ & $\begin{array}{l}\text { - Considered highly valid and reliable method } \\
\text { - Developed by a joint effort of } 97 \text { orthodontists across } 9 \text { countries } \\
\text { Occlusal trait scores include: } \\
\text { 1. Upper and lower segment alignment } \\
\text { 2. Anterior vertical relationship, centerline, impacted teeth, upper and lower buccal } \\
\text { segment alignment, buccal segment AP relationship, buccal segment vertical } \\
\text { relationship, crossbite, missing teeth } \\
\text { 3. Esthetic assessment based on IOTN esthetic component, overjet, reverse overjet, } \\
\text { upper and lower incisor inclination relative to occlusal plane, upper arch crowding/ } \\
\text { spacing, lip competency }\end{array}$ \\
\hline $\begin{array}{l}\text { American Board of } \\
\text { Orthodontics (ABO)/ } \\
\text { Discrepancy Index } \\
\text { - Cangialosi et al } \\
(2004,2011-12)^{50.51}\end{array}$ & $\begin{array}{l}\text { - Developed as an index to represent the objective evaluation of difficulty of the case } \\
\text { presented for phase III ABO examination. } \\
\text { - Called as discrepancy index (DI) } \\
\text { Evaluates case complexity based on criteria of case difficulty by evaluating dental } \\
\text { models and cephalometric parameters. } \\
\text { Determinants are overjet, overbite, openbite, crowding, occlusion, lingual/buccal } \\
\text { posterior crossbite, cephalometrics. }\end{array}$ \\
\hline $\begin{array}{l}\text { Index of Orthodontic } \\
\text { Treatment Complexity (IOTC) } \\
\text { - Liewellyn et al (2007) }\end{array}$ & $\begin{array}{l}\text { - A simple method measuring relatively few traits } \\
\text { - } \quad \text { Can be used on patients and study casts } \\
\text { - } \quad \text { Avoids the need to use different indices for different forms of assessment } \\
\text { - Identification of the level of expertise needed to treat a specific case, allocation of } \\
\text { health care resources, appropriate recognition of professionals undertaking complex } \\
\text { care, and provision for better patient information regarding the likely complexity of the } \\
\text { treatment. }\end{array}$ \\
\hline
\end{tabular}

\section{DISCUSSION}

The present article reviewed various orthodontic indices available in the literature. Classification of orthodontic indices proposed by Shaw et $a^{7}$ is the most comprehensive system found. Descriptions on indices and methods of the assessment of malocclusion mentioned in the present article are based on the opinion of respective authors.

Initially malocclusions used to be described as per the clinical features on qualitative basis, later there have been attempts to quantify them in scale and scores. The present article also attempts to categorize various orthodontic indices into qualitative and quantitative methods.

Most of the orthodontic indices use study model for analysis, however direct examination on patients and photographs have also been used in other systems. Study model serves as a patient awareness tool for the patients and allows three-dimensional analyses. Traditionally, the opinion and experience of the orthodontist are used to explain the discrepancy of the dental arches. In fact, no single classification is found to be ideal, accurate, valid and reliable for assessing the malocclusion and yet that is simple. There have been many disagreements among the authors and researchers about various indices, therefore many newer systems are developed to fulfill the shortcomings of the antecedents. Angles classification ${ }^{8}$ is still the most widely used system in clinical and epidemiological purposes and IOTN ${ }^{21}$ is perhaps the most accepted index for assessing treatment need. ABO Discrepancy Index ${ }^{50,51}$ serves as the contemporary tool for complexity scores and academic evaluations.

\section{OJN}

\section{REFERENCES}

1. Asbell MB. A brief history of orthodontics. Am J Orthod Dentofac Orthop1990; 98(3):206-13.

2. Russell AL. A system of classification and scoring for prevalence surveys of periodontal disease. J Dent Research1956; 35:350-9.

3. Jago JD. The epidemiology of dental occlusion: A critical appraisal. J Pub Health Dent 1974; 34:80-93.

4. World Health Organization. An international methodology for epidemiological study of oral disease. Manual No.5: Epidemiological studies of periodontal disease. First draft. Geneva, 1966.

5. Brzroukov V, Freer TJ, Helm S, Kalamkarov H, Sarodoinfirrir J, Solow B. Basic methods of recording malocclusion: A systematic approach for planning treatment. Bull WHO 1979; 57:955-61.

6. Bjork A, Krebs AA, Solow B. A method for epidemiological registration of malocclusion. Acta Odontol Scand. 1964; $22: 27-41$.

7. Farahani AB. An insight into four Orthodontic Treatment Need Indices. Progress Orthod 201 1; 12(2):132-42.

8. Angle EH. Classification of malocclusion. Dent Cosmos 1899; 41:248-64. 
9. Ballard CF, Wayman JB. A report on a survey of the orthodontic requirements of 310 army apprentices. Dent Pract Dent Rec 1965; 15: 221-6.

10. Proffit WR, Ackerman JL. Rating the characteristics of malocclusion: A systematic approach for planning treatment. Am J Orthod 1973; 64(3):258-69.

11. Massler M, Frankel JM. Prevalence of malocclusion in children aged 14-18 years. Am J Orthod 1951; 37:751-68.

12. VanKirk LK, Pennell EH. Assessment of malocclusion in population groups. Am J Orthod 1959; 45(10):752-58.

13. Poulton DR, Aaronson SA. The relationship between occlusion and periodontal status. Am J Orthod 1961; 47(9):690-9.

14. Summers CJ, Arbor A. The Occlusal Index: A system for scoring and identifying occlusal disorders. Am J Orthod. $1971 ; 59(6): 552-67$.

15. Baume, LJ; Horowitz, HS; Summers, CJ; Dirks, BO; Brown, WAB; Carlos, JP. A method for measuring occlusal traits. Int Dent J $1973 ; 23: 530-37$.

16. Little RM. The Irregularity Index. Am J Orthod 1975; 68:554-63.

17. Draker HL. Handicapping labio-lingual deviations: A proposed index for public health purposes. Am J Orthod 1960; 46:295-305.

18. Linder-Aronson S. Orthodontists in the Swedish public dental health service. Transactions Eur Orthod Soc 1974:233-40.

19. Linder-Aronson S, Fridh G, Jensen R. Need of Orthodontic treatment and orthodontic specialists in Sweden. Swed Dent J 1976; 68:383402.

20. Cons NC, Jenny J, Kohout FJ. DAl: The Dental Aesthetic Index. lowa City, lowa: College of Dentistry, University of lowa; 1986.

21. Brook PH. Shaw WC. The development of an index of orthodontic treatment priority. Eur J Orthod 1989; 20:309-20.

22. Daniels C, Richmond S. The Development of the Index of Complexity, Outcome \& Need (ICON). J Orthod. $2000 ; 27$ (2):143-48.

23. Richmond S, Shaw WC, Roberts CT, Andrews M. The PAR Index (Peer Assessment Rating): Methods to determine orthodontic treatment in terms of improvement and standards. Eur J Orthod 1992; 14(3):180-87.

24. Llewellyn SK, Hamdan AM, Rock WP. An Index of Orthodontic treatment Complexity. Eur J Orthod 2007; 29:186-192.

25. Agarwal A, Mathur R. An Overview of Orthodontic Indices. World J Dent 2012; 3(1):77-86.

26. Tang ELK, Wei SHY. Recording and measuring malocclusion: A review of the literature. Am J Orthod Dentofacial Orthop 1993; 103: 344-51.

27. Houston WJB, Stephens CD, Tulley WJ. A Textbook of Orthodontics, Great Britain: Wright, 1992:1-13.

28. Rinchuse DJ. Ambiguities of Angle's classification. Angle Orthod 1988, 59:295-298.

29. Stallard $\mathrm{H}$. The general prevalence of gross symptoms of malocclusion. Dent Cosmos 1932; 74:29-37.

30. McCall JO. A study of malocclusion in pre-school and school children. Dent Items Interest 1944; 131-33.

31. Sclare R. Orthodontics and the school children: A survey of 680 children. Br Dent J 1945; 79:278-80.

32. Fisk R. When malocclusion concerns the public. Can Dent Assoc J 1960; 26(7):397-412.

33. Danish National Board of Health. Memorandum of orthodontic screening and indications for orthodontic treatment. P.O. Box 2020, DK1012 Copenhagen K, 1990.

34. Salonen L, Mohlin B, Gotzlinger B, Hellden L. Need and demand for orthodontic treatment in adult Swedish population. Euro J Orthod 1992; 14:359-368.

35. Atack NE, Hathorn IS, Semb G, Dowell T, Sandy JR. A new index for assessing surgical outcome in unilateral cleft lip and palate subjects aged five: reproducibility and validity. Cleft Palate Craniofac J 1997; 34:242-246.

36. Nollet PJPM, Katsaros C, Van't Hof MA, Bongaarts CA, Semb G, Shaw WC, Kuijpers-Jagtman AM. Photographs of study casts: An alternative medium for rating dental arch relationships in unilateral cleft lip and palate. Cleft Palate Craniofac J. 2004; 41:646-650.

37. Liao Y, Huang C, Lin I. Intraoral photographs for rating dental arch relationships in unilateral cleft lip and palate. Cleft Palate Craniofac J. 2009; 46:415-419.

38. Han, H, Davidson WM. A useful insight into 2 occlusal indexes: HLD (Md) and HLD (CalMod). Am J Orthod Dentofacl Orthopedics 2001; 120:247-253.

39. Parker WS. The HLD (CalMod) index and the index question. Am J Orthod Dentofac Orthopedics 1998; 114:134-141.

40. Grainger RM. Malocclusion Severity estimate Progress Report, Series VI. Burlington Orthodontic Research Centre. 1960-61:9-1 1.

41. Grainger RM. Orthodontic Treatment Priority Index. 1967. Public Health Service Publication No. 1000, Series 2, No. 25, US Government Printing Office, Washington DC.

42. Salzmann JA. Handicapping malocclusion assessment to establish treatment priority. Am J Orthod. 1968; 54(10):749-69.

43. Eismann D. A method of evaluating the efficiency of orthodontic treatment. Trans Eur Orthod Soc 1974:223-32.

44. Farc 'nik F, Korpar M, Premik M, Zorec R. Numerical evaluation of malocclusion in study models of the mixed dentition. ZobozdravVestn 1985; 40:169-76.

45. Farc 'nik F, Korpar M, Premik M, Zorec R. An attempt at numerically evaluating dysgnathias in the deciduous dentition. Stomatol DDR 1988; 38:386-91.

46. Mars M, Plint DA, Houston WJB, Bergland O, Semb G. The Goslon Yardstick: A new system of assessing dental arch relationship in children with unilateral cleft lip and palate. Cleft Palate J 1987; 24:4:314-322.

47. Evans R, Shaw WC. Preliminary evaluation of an illustrated scale for rating dental attractiveness. Euro J Orthod 1987; 9:314-318.

48. Espeland, LV; Ivarsson, K; Stenvik, A. A new Norwegian index of orthodontic treatment need related to orthodontic concern among 11-year-olds and their parents. Comm Dent Oral Epidemio 1992; 20:274-279.

49. Russo E, Grippaudo C, Marchionni P, Deli R. II ROMA index come metronomo della terapia ortodontica nel paziente in crescita. Procedings National Congress of SIDO, Firenze, 28-31 Oct. 1998.

50. Cangialosi TJ, Riolo ML, Owens SEJ. The ABO discrepancy index: A measure of case complexity. Am J Orthod Dentofac Orthop 2004; 125(3):270-8.

51. http://www.americanboardorthod.com/professionals/downloads/Discrepancy\%20Index\%Scoring\%20system.pdf Salzmann JA 